Article

\title{
Evaluation of Landsat-8 and Sentinel-2A Aerosol Optical Depth Retrievals across Chinese Cities and Implications for Medium Spatial Resolution Urban Aerosol Monitoring
}

\author{
Zhongbin Li ${ }^{1}$, David P. Roy ${ }^{2}{ }^{(0}$, Hankui K. Zhang ${ }^{1, *}{ }^{\mathbb{D}}$, Eric F. Vermote ${ }^{3}$ and Haiyan Huang ${ }^{1}(\mathbb{D}$ \\ 1 Geospatial Sciences Center of Excellence, South Dakota State University, Brookings, SD 57007, USA; \\ zhongbin.li@sdstate.edu (Z.L.); haiyan.huang@sdstate.edu (H.H.) \\ 2 Department of Geography, Environment, \& Spatial Sciences and Center for Global Change and Earth \\ Observations, Michigan State University, East Lansing, MI 48824, USA; dproy@msu.edu \\ 3 Terrestrial Information System Laboratory (Code 619), NASA Goddard Space Flight Center, \\ Greenbelt, MD 20771, USA; eric.f.vermote@nasa.gov \\ * Correspondence: hankui.zhang@sdstate.edu
}

Received: 4 December 2018; Accepted: 4 January 2019; Published: 10 January 2019

\begin{abstract}
In urban environments, aerosol distributions may change rapidly due to building and transport infrastructure and human population density variations. The recent availability of medium resolution Landsat- 8 and Sentinel-2 satellite data provide the opportunity for aerosol optical depth (AOD) estimation at higher spatial resolution than provided by other satellites. AOD retrieved from $30 \mathrm{~m}$ Landsat- 8 and $10 \mathrm{~m}$ Sentinel-2A data using the Land Surface Reflectance Code (LaSRC) were compared with coincident ground-based Aerosol Robotic Network (AERONET) Version 3 AOD data for 20 Chinese cities in 2016. Stringent selection criteria were used to select contemporaneous data; only satellite and AERONET data acquired within $10 \mathrm{~min}$ were considered. The average satellite retrieved AOD over a $1470 \mathrm{~m} \times 1470 \mathrm{~m}$ window centered on each AERONET site was derived to capture fine scale urban AOD variations. AERONET Level 1.5 (cloud-screened) and Level 2.0 (cloud-screened and also quality assured) data were considered. For the 20 urban AERONET sites in 2016 there were 106 (Level 1.5) and 67 (Level 2.0) Landsat-8 AERONET AOD contemporaneous data pairs, and 118 (Level 1.5) and 89 (Level 2.0) Sentinel-2A AOD data pairs. The greatest AOD values (>1.5) occurred in Beijing, suggesting that the Chinese capital was one of the most polluted cities in China in 2016. The LaSRC Landsat-8 and Sentinel-2A AOD retrievals agreed well with the AERONET AOD data (linear regression slopes $>0.96$; coefficient of determination $\mathrm{r}^{2}>0.90$; root mean square deviation $<0.175$ ) and demonstrate that the LaSRC is an effective and applicable medium resolution AOD retrieval algorithm over urban environments. The Sentinel-2A AOD retrievals had better accuracy than the Landsat- 8 AOD retrievals, which is consistent with previously published research. The implications of the research and the potential for urban aerosol monitoring by combining the freely available Landsat- 8 and Sentinel-2 satellite data are discussed.
\end{abstract}

Keywords: Landsat-8; Sentinel-2; aerosol optical depth (AOD); urban

\section{Introduction}

In much of Asia, rapid economic growth has resulted in increased air pollution [1-4]. In particular, the increased occurrence of urban haze, characterized by high concentrations of fine particulate matter with diameter less than $2.5 \mu \mathrm{m}$ (PM2.5), has received growing attention due to human health and quality of life concerns $[5,6]$. In situ air quality measurements provide high temporal resolution 
observations but can be difficult to extrapolate spatially. With wide spatial and repetitive coverage, satellite-based remote sensing provides an effective way to quantify and map aerosol properties and in particular the aerosol optical depth (AOD), i.e., the amount of incoming solar radiation that is scattered and absorbed by aerosols at a given wavelength [7]. Most satellite AOD retrieval algorithms assume prior knowledge of the surface reflectance and the aerosol type and use radiative transfer modelled relationships between the observed reflectance and AOD [8]. For example, the Moderate Resolution Imaging Spectroradiometer (MODIS) AOD product is derived over land using four aerosol models and fixed blue, red and $2.1 \mu \mathrm{m}$ wavelength reflectance ratios [9]. Satellite based AOD products have been developed and used to estimate the concentration of fine particulate matter for epidemiological and air quality research [10-13]. However, satellite AOD products are defined at relatively coarse spatial resolution. For example, AOD products have been developed using data from Total Ozone Mapping Spectrometer (TOMS) at $1^{\circ}$ resolution [14], Polarization and Directionality of Earth Reflectances (POLDER) at $1 / 6^{\circ}$ resolution [15], Multi-angle Imaging SpectroRadiometer (MISR) at $17.6 \mathrm{~km}$ resolution [16], Medium Resolution Imaging Spectrometer (MERIS) at $10 \mathrm{~km}$ resolution [17], Visible Infrared Imaging Radiometer Suite (VIIRS) at $6 \mathrm{~km}$ resolution [18], Himawari-8 Geostationary at $0.05^{\circ}$ resolution [19], and MODIS at $10 \mathrm{~km}, 3 \mathrm{~km}[9,20]$ and $1 \mathrm{~km}$ resolution [21]. Coarse resolution products are less suitable for studying aerosols in urban environments where aerosol distributions may change at finer spatial scales due to factors including spatial variations in building and transport infrastructure and human population densities [22-24].

The recently launched Landsat- 8 and Sentinel- 2 satellites can be used to derive AOD data at $30 \mathrm{~m}$ and $10 \mathrm{~m}$ resolution respectively and so have the potential for urban aerosol monitoring. For example, AOD retrieved from $30 \mathrm{~m}$ Landsat-8 OLI spatially aggregated to $500 \mathrm{~m}$ [25] were compared with contemporaneous ground-based Aerosol Robotic Network (AERONET) AOD measurements across the city of Beijing, China. Recently, AOD retrieved from $30 \mathrm{~m}$ Landsat- 8 and $10 \mathrm{~m}$ Sentinel-2A data were compared with contemporaneous AERONET AOD measurements over 19 globally distributed urban and non-urban AERONET sites [26].

The goals of this research are to study the accuracy of AOD retrievals from the Landsat- 8 and Sentinel-2 satellites and provide insights into their suitability for medium spatial resolution urban aerosol monitoring across China. A year of Landsat-8 and Sentinel-2A $550 \mathrm{~nm}$ AOD data, retrieved using the recently published Land Surface Reflectance Code (LaSRC), were compared with coincident ground-based AERONET Version 3 AOD data at 20 Chinese cities. For fair comparison, the $500 \mathrm{~nm}$ AERONET AOD measurements were converted to $550 \mathrm{~nm}$ equivalent values using an established Ångström exponent interpolation method. The LaSRC average AOD retrievals over $1470 \mathrm{~m} \times 1470 \mathrm{~m}$ (i.e., $49 \times 4930 \mathrm{~m}$ Landsat- 8 pixels and $147 \times 14710 \mathrm{~m}$ Sentinel-2A pixels) centered on the AERONET site locations were compared with the temporally closest AERONET AOD measured within 10 min of the satellite overpass. Differences between the LaSRC satellite AOD retrievals and AERONET AOD measurements were quantified statistically. The paper concludes with a discussion of the implications of this study for satellite based urban aerosol monitoring at moderate spatial resolution.

\section{Data}

\subsection{AERONET Data}

The AERONET is a network of globally distributed ground-based sun and sky scanning radiometers that provide near-continuous (typically every three minutes) daytime measurements of spectral solar irradiance, spectral aerosol optical thickness, water vapor, and inversion aerosol products $[27,28]$. The AERONET data include spectral AOD in the ultraviolet to near infrared (typically from $340 \mathrm{~nm}$ or $440 \mathrm{~nm}$, to $1020 \mathrm{~nm}$ or $1640 \mathrm{~nm}$, depending on the site radiometer), Ångström exponents at different wavelengths, and column water vapor $\left(\mathrm{g} / \mathrm{cm}^{2}\right)$. The most recent Version 3.0 data [29] were obtained from the AERONET web site (http:/ / aeronet.gsfc.nasa.gov/, accessed on 28 August 2018). The data are categorized into different quality levels. In this study the higher quality 
Level 1.5 (cloud-screened) and Level 2.0 (cloud-screened and also quality assured) data were used. The AERONET AOD has a +0.02 bias and one sigma uncertainty of 0.02 [29].

All the Version 3.0 AERONET data over mainland China, Hong Kong, and Taiwan available in 2016 were considered. A whole year of data was used to capture a representative range in AOD across China. Two AERONET sites were removed however as they were not in or close to urban areas (checked by comparison with Google Map satellite images). The majority of the remaining 26 sites had both Level 1.5 and Level 2.0 data and were in mainland China (Figure 1). Site differences in the annual amount of AERONET data and the processing level (Table 1) reflect cloud conditions, and AERONET site operational differences.

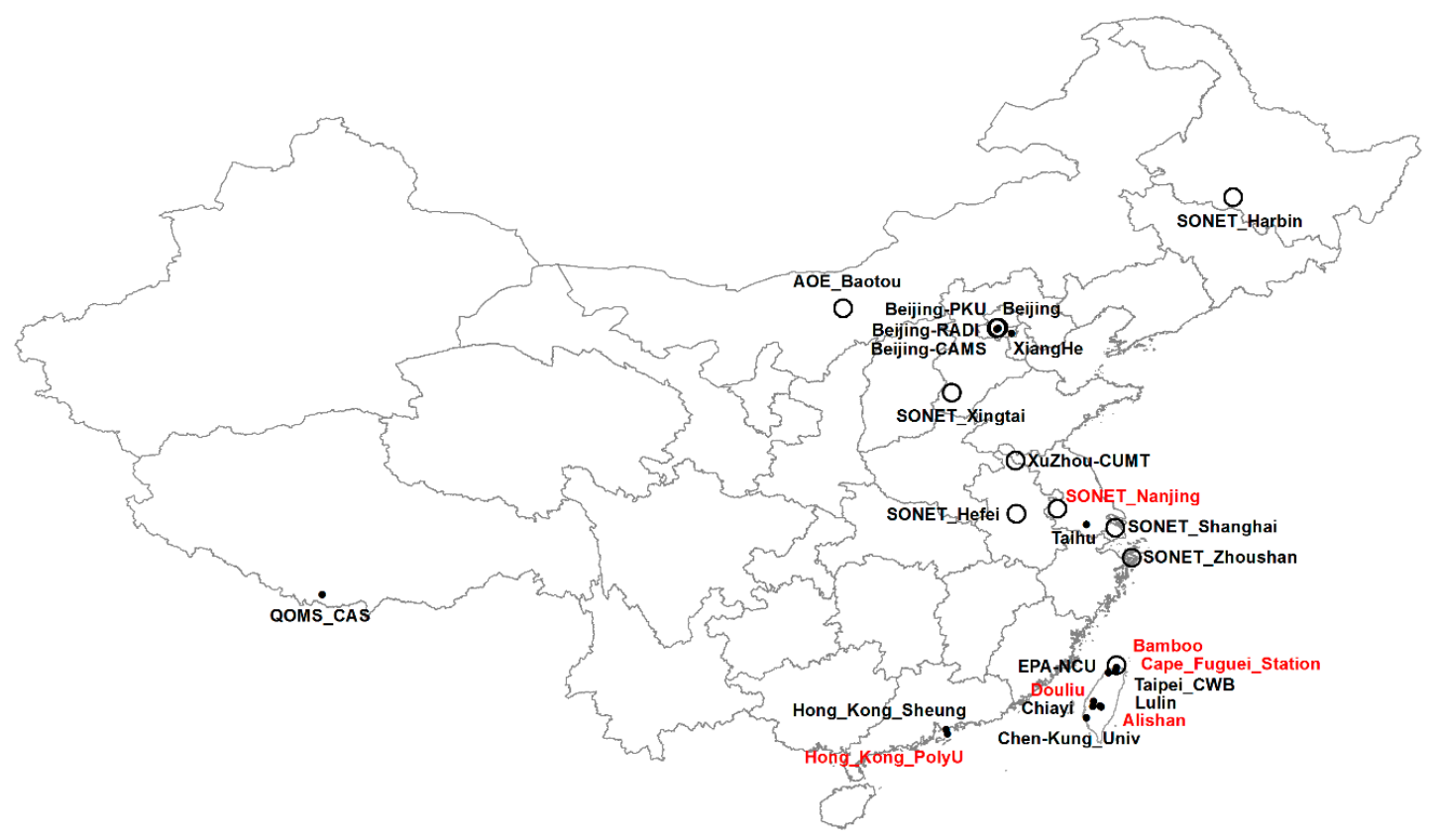

Figure 1. Locations of 26 urban AERONET sites with Level 1.5 data (open circles, 11 sites) and with both Level 1.5 and Level 2.0 data (small solid circles, 15 sites) in 2016. The six sites shown in red were not used because they had no contemporaneous AERONET and satellite data after application of the stringent filtering criteria described in Section 3.2.

Table 1. The 26 urban AERONET site (Figure 1) short names, geographic locations, and 2016 AERONET data availability. The coordinates of the Landsat- 8 images (path/row) and Sentinel-2A tiles (tile ID) and 2016 data availability at each AERONET site are also summarized.

\begin{tabular}{|c|c|c|c|c|c|}
\hline $\begin{array}{c}\text { AERONET Site } \\
\text { (Latitude, Longitude) }\end{array}$ & $\begin{array}{c}\text { Number of Days in } \\
2016 \text { with } \\
\text { AERONET Level } 1.5 \\
\text { (Level 2.0) Data }\end{array}$ & $\begin{array}{l}\text { Landsat-8 } \\
\text { Path/Row }\end{array}$ & $\begin{array}{c}\text { Number of } \\
\text { Landsat-8 Images } \\
\text { over the AERONET } \\
\text { Site in } 2016\end{array}$ & $\begin{array}{l}\text { Sentinel-2A } \\
\text { Tile ID }\end{array}$ & $\begin{array}{c}\text { Number of } \\
\text { Sentinel-2A Images } \\
\text { over the AERONET } \\
\text { Site in } 2016\end{array}$ \\
\hline $\begin{array}{c}\text { AOE_Baotou } \\
\left(40.852^{\circ} \mathrm{N}, 109.629^{\circ} \mathrm{E}\right)\end{array}$ & $173(0)$ & $\begin{array}{l}127 / 32 \\
128 / 31 \\
128 / 32\end{array}$ & 66 & 49TCF & 56 \\
\hline $\begin{array}{c}\text { Beijing } \\
\left(39.977^{\circ} \mathrm{N}, 116.381^{\circ} \mathrm{E}\right)\end{array}$ & $243(243)$ & $123 / 32$ & 22 & 50TMK & 59 \\
\hline $\begin{array}{c}\text { Beijing-CAMS } \\
\left(39.933^{\circ} \mathrm{N}, 116.317^{\circ} \mathrm{E}\right)\end{array}$ & 299 (299) & $123 / 32$ & 22 & 50TMK & 59 \\
\hline $\begin{array}{c}\text { Beijing_PKU } \\
\left(39.992^{\circ} \mathrm{N}, 116.310^{\circ} \mathrm{E}\right)\end{array}$ & $147(0)$ & $123 / 32$ & 22 & 50TMK & 59 \\
\hline $\begin{array}{c}\text { Beijing_RADI } \\
\left(40.005^{\circ} \mathrm{N}, 116.379^{\circ} \mathrm{E}\right)\end{array}$ & $224(0)$ & $123 / 32$ & 22 & 50TMK & 59 \\
\hline $\begin{array}{l}\text { Hong_Kong_PolyU } \\
\left(22.303^{\circ} \mathrm{N}, 114.180^{\circ} \mathrm{E}\right)\end{array}$ & $53(53)$ & $\begin{array}{l}121 / 45 \\
122 / 45 \\
122 / 44\end{array}$ & 45 & $\begin{array}{l}\text { 50QKK } \\
49 \mathrm{QHE}\end{array}$ & 122 \\
\hline
\end{tabular}


Table 1. Cont.

\begin{tabular}{|c|c|c|c|c|c|}
\hline $\begin{array}{c}\text { AERONET Site } \\
\text { (Latitude, Longitude) }\end{array}$ & $\begin{array}{l}\text { Number of Days in } \\
2016 \text { with } \\
\text { AERONET Level } 1.5 \\
\text { (Level 2.0) Data }\end{array}$ & $\begin{array}{l}\text { Landsat-8 } \\
\text { Path/Row }\end{array}$ & $\begin{array}{c}\text { Number of } \\
\text { Landsat-8 Images } \\
\text { over the AERONET } \\
\text { Site in } 2016\end{array}$ & $\begin{array}{l}\text { Sentinel-2A } \\
\text { Tile ID }\end{array}$ & $\begin{array}{c}\text { Number of } \\
\text { Sentinel-2A Images } \\
\text { over the AERONET } \\
\text { Site in } 2016\end{array}$ \\
\hline $\begin{array}{l}\text { Hong_Kong_Sheung } \\
\left(22.483^{\circ} \mathrm{N}, 114.117^{\circ} \mathrm{E}\right)\end{array}$ & $52(52)$ & $\begin{array}{l}121 / 45 \\
122 / 45 \\
122 / 44\end{array}$ & 49 & $\begin{array}{l}\text { 50QKK } \\
49 \mathrm{QHE}\end{array}$ & 122 \\
\hline $\begin{array}{c}\text { QOMS_CAS } \\
\left(28.365^{\circ} \mathrm{N}, 86.948^{\circ} \mathrm{E}\right)\end{array}$ & 198 (198) & $\begin{array}{l}140 / 40 \\
140 / 41\end{array}$ & 35 & 45RVM & 21 \\
\hline $\begin{array}{c}\text { SONET_Harbin } \\
\left(45.705^{\circ} \mathrm{N}, 126.614^{\circ} \mathrm{E}\right)\end{array}$ & $33(0)$ & $\begin{array}{l}117 / 28 \\
117 / 29 \\
118 / 28\end{array}$ & 46 & $\begin{array}{l}\text { 52TCR } \\
\text { 51TYL }\end{array}$ & 54 \\
\hline $\begin{array}{c}\text { SONET_Hefei } \\
\left(31.905^{\circ} \mathrm{N}, 117.162^{\circ} \mathrm{E}\right)\end{array}$ & $23(0)$ & $121 / 38$ & 17 & 50SNA & 29 \\
\hline $\begin{array}{c}\text { SONET_Nanjing } \\
\left(32.115^{\circ} \mathrm{N}, 118.957^{\circ} \mathrm{E}\right)\end{array}$ & $11(0)$ & $120 / 38$ & 17 & 50SPA & 33 \\
\hline $\begin{array}{c}\text { SONET_Shanghai } \\
\left(31.284^{\circ} \mathrm{N}, 121.481^{\circ} \mathrm{E}\right)\end{array}$ & $16(0)$ & $118 / 38$ & 17 & 51RUQ & 62 \\
\hline $\begin{array}{c}\text { SONET_Xingtai } \\
\left(37.182^{\circ} \mathrm{N}, 114.360^{\circ} \mathrm{E}\right)\end{array}$ & $22(0)$ & $124 / 34$ & 20 & $\begin{array}{l}\text { 50SKG } \\
49 S G B\end{array}$ & 74 \\
\hline $\begin{array}{l}\text { SONET_Zhoushan } \\
\left(29.994^{\circ} \mathrm{N}, 122.188^{\circ} \mathrm{E}\right)\end{array}$ & $13(0)$ & $\begin{array}{l}118 / 39 \\
117 / 39\end{array}$ & 26 & 51RVP & 23 \\
\hline $\begin{array}{c}\text { Taihu } \\
\left(31.421^{\circ} \mathrm{N}, 120.215^{\circ} \mathrm{E}\right)\end{array}$ & 153 (129) & $119 / 38$ & 14 & $\begin{array}{l}\text { 51RTQ } \\
\text { 50RQV }\end{array}$ & 77 \\
\hline $\begin{array}{c}\text { XiangHe } \\
\left(39.754^{\circ} \mathrm{N}, 116.962^{\circ} \mathrm{E}\right)\end{array}$ & 289 (289) & $\begin{array}{l}123 / 32 \\
122 / 32 \\
122 / 33\end{array}$ & 60 & 50TMK & 59 \\
\hline $\begin{array}{c}\text { XuZhou-CUMT } \\
\left(34.217^{\circ} \mathrm{N}, 117.142^{\circ} \mathrm{E}\right)\end{array}$ & $258(0)$ & $\begin{array}{l}121 / 36 \\
121 / 37 \\
122 / 36\end{array}$ & 51 & 50SNC & 29 \\
\hline $\begin{array}{c}\text { Alishan } \\
\left(23.508^{\circ} \mathrm{N}, 120.813^{\circ} \mathrm{E}\right)\end{array}$ & $14(14)$ & $\begin{array}{l}117 / 44 \\
118 / 43 \\
118 / 44\end{array}$ & 58 & $\begin{array}{l}\text { 51QTG } \\
\text { 50QRM }\end{array}$ & 38 \\
\hline $\begin{array}{c}\text { Bamboo } \\
\left(25.187^{\circ} \mathrm{N}, 121.535^{\circ} \mathrm{E}\right)\end{array}$ & $11(11)$ & $\begin{array}{l}117 / 42 \\
117 / 43\end{array}$ & 27 & 51RUH & 14 \\
\hline $\begin{array}{l}\text { Cape_Fuguei_Station } \\
\left(25.297^{\circ} \mathrm{N}, 121.538^{\circ} \mathrm{E}\right)\end{array}$ & $16(0)$ & $\begin{array}{l}117 / 42 \\
117 / 43\end{array}$ & 27 & $\begin{array}{l}\text { 51RUJ } \\
\text { 51RUH }\end{array}$ & 28 \\
\hline $\begin{array}{c}\text { Chen-Kung_Univ } \\
\left(23.000^{\circ} \mathrm{N}, 120.217^{\circ} \mathrm{E}\right)\end{array}$ & $137(80)$ & $118 / 44$ & 20 & $\begin{array}{l}\text { 51QTF } \\
\text { 50QRL }\end{array}$ & 26 \\
\hline $\begin{array}{c}\text { Chiayi } \\
\left(23.496^{\circ} \mathrm{N}, 120.496^{\circ} \mathrm{E}\right)\end{array}$ & $144(144)$ & $\begin{array}{l}118 / 44 \\
117 / 44 \\
118 / 43\end{array}$ & 39 & $\begin{array}{l}\text { 51QTG } \\
\text { 50QRM }\end{array}$ & 38 \\
\hline $\begin{array}{c}\text { Douliu } \\
\left(23.712^{\circ} \mathrm{N}, 120.545^{\circ} \mathrm{E}\right)\end{array}$ & 19 (19) & $\begin{array}{l}117 / 44 \\
118 / 43 \\
118 / 44\end{array}$ & 58 & $\begin{array}{l}\text { 51QTG } \\
\text { 50QRM }\end{array}$ & 38 \\
\hline $\begin{array}{c}\text { EPA-NCU } \\
\left(24.968^{\circ} \mathrm{N}, 121.185^{\circ} \mathrm{E}\right)\end{array}$ & $201(201)$ & $\begin{array}{l}117 / 43 \\
118 / 42 \\
118 / 43\end{array}$ & 47 & 51RUH & 14 \\
\hline $\begin{array}{c}\text { Lulin } \\
\left(23.469^{\circ} \mathrm{N}, 120.874^{\circ} \mathrm{E}\right)\end{array}$ & $190(190)$ & $117 / 44$ & 19 & $\begin{array}{l}\text { 51QTG } \\
\text { 51QTF } \\
\text { 50QRM }\end{array}$ & 51 \\
\hline $\begin{array}{c}\text { Taipei_CWB } \\
\left(25.030^{\circ} \mathrm{N}, 121.500^{\circ} \mathrm{E}\right)\end{array}$ & 188 (188) & $117 / 43$ & 16 & 51RUH & 14 \\
\hline
\end{tabular}

\subsection{Landsat-8 and Sentinel-2A Data}

Landsat-8 was launched in 2013 and carries the optical wavelength Operational Land Imager (OLI) and the thermal wavelength Thermal Infrared Sensor (TIRS) [30]. The OLI is a 12-bit multispectral sensor providing eight reflective wavelength $30 \mathrm{~m}$ observations from $435 \mathrm{~nm}$ to $2294 \mathrm{~nm}$ [31]. The OLI data are provided in approximately $185 \times 180 \mathrm{~km}$ images defined in Worldwide Reference System (WRS) path/row coordinates in the Universal Transverse Mercator (UTM) projection. Landsat-8 has 
a 16-day revisit cycle and so nominally there are 22 or 23 OLI images over each path/row location per year. Only Landsat-8 Collection 1 Tier 1 data were used in this study as they are the highest quality data and are radiometrically calibrated and orthorectified [32]. The image-to-image registration accuracy of the Landsat- 8 Collection 1 Tier 1 scenes is $\leq 12 \mathrm{~m}$ radial root mean square error [33].

Sentinel-2A was launched in June 2015 and carries the optical wavelength multi-spectral instrument (MSI). The MSI is a 12-bit multispectral sensor with four $10 \mathrm{~m}$, six $20 \mathrm{~m}$ and three $60 \mathrm{~m}$ reflective bands observations from $433 \mathrm{~nm}$ to $2280 \mathrm{~nm}$ [34]. Sentinel-2A has a 10-day revisit cycle and the data are provided in fixed $109 \times 109 \mathrm{~km}$ spatially overlapping tiles in the UTM projection [35]. The image-to-image registration accuracy of the data was $16 \mathrm{~m}$ before 15 June 2016 and was $4 \mathrm{~m}$ after this date [36] when the European Space Agency updated the processing software [37].

All of the Landsat-8 OLI and Sentinel-2A MSI data available in 2016 over the 26 urban AERONET sites were obtained. Top of atmosphere (TOA) reflectance OLI images were obtained from the United States Geological Survey portal (https://earthexplorer.usgs.gov/) and TOA Sentinel-2A L1C tile products were obtained from the European Space Agency portal (https: / / scihub.copernicus.eu/dhus). This provided between 14 and $66($ mean $=20)$ Landsat-8 OLI images and between 14 and $122($ mean = 30) Sentinel-2A tile acquisitions at each AERONET site (Table 1). More Sentinel-2A acquisitions were available because of the higher 10-day satellite revisit cycle.

\section{Methods}

\subsection{Landsat-8 and Sentinel-2A Aerosol Optical Depth (AOD) Retrieval}

Reliable surface monitoring with optical wavelength remotely sensed data requires atmospheric correction to minimize the scattering and absorbing effects of atmospheric gases and aerosols. Radiative transfer algorithms and atmospheric characterization data are used for automated large-area atmospheric correction $[38,39]$. The correction of aerosol effects is particularly challenging because aerosols are highly variable in space and time $[28,40]$. In this study, the LaSRC (Land Surface Reflectance Code) V3.5.5 atmospheric correction algorithm [41] was used. LaSRC code is publicly available (https:/ / github.com/USGS-EROS/espa-surface-reflectance/tree/master/lasrc) and has been operationally used by the United States Geological Survey (USGS) to generate Landsat Analysis Ready Data (ARD) [32] and by NASA to generate Harmonized Landsat and Sentinel-2 surface reflectance products [42]. The LaSRC algorithm was developed for atmospheric correction of Landsat-8 imagery [41] and has been adapted for Sentinel-2A application [26,43]. It is based on the 6SV radiative transfer code [44]. The AOD retrieval takes advantage of the short wavelength red and blue bands on the Landsat- 8 and Sentinel-2 sensors. Two surface reflectance ratios, red to blue and red to ultra-blue, and the difference between them are used to invert the AOD using a global coarse resolution $\left(0.05^{\circ}\right)$ ratio data set derived from MODIS and MISR data, and expressed as a function of a mid-infrared vegetation index [41]. A fixed urban-clean aerosol model [28] is assumed. Despite using a fixed aerosol model, the Ångström exponent (related to the dependence of AOD with wavelength) is not fixed [41]. This has a similar effect as allowing a dynamic aerosol model with varying aerosol size distribution and refractive index $[14,40]$ and is needed for aerosol retrieval over regions with different aerosol types. The LaSRC AOD is defined at $550 \mathrm{~nm}$ for each $10 \mathrm{~m}$ (Sentinel-2A) and $30 \mathrm{~m}$ (Landsat-8) pixel, and the LaSRC code was modified to write out the AOD values. The LaSRC algorithm also generates a per-pixel cloud mask using the red-to-blue surface reflectance ratios [41]. The LaSRC $10 \mathrm{~m}$ (Sentinel-2A) and $30 \mathrm{~m}$ (Landsat-8) cloud masks were used in this study to remove cloud contaminated pixels.

\subsection{Comparison of Contemporaneous AERONET and Satellite Retrieved AOD}

The ground-based AERONET $500 \mathrm{~nm}$ AOD measurements were compared with the LaSRC satellite retrieved AOD $550 \mathrm{~nm}$ data. First, the AERONET $500 \mathrm{~nm}$ AOD measurements were converted to $550 \mathrm{~nm}$ equivalent values using the standard Ångström exponent interpolation method [45] as: 


$$
\tau(550)=\tau(500)(500 / 550)^{\alpha}
$$

where $\tau(550)$ is the interpolated AERONET 550nm AOD data, $\tau(500)$ is the AERONET $500 \mathrm{~nm}$ AOD measurement, and $\alpha$ is the AERONET 440-675 nm Ångström exponent. Other studies have suggested that a quadratic or cubic relationship may better characterize the AOD dependence with wavelength in the logarithmic scale [46]. However, as the interpolated wavelength $(550 \mathrm{~nm})$ is close to the observed wavelength $(500 \mathrm{~nm})$, the log-linear relationship is used as Equation (1), and following on from well-established MODIS approaches [47,48].

The following temporal and spatial data selection criteria were applied to select contemporaneous satellite and AERONET AOD data. At each AERONET site the closest AERONET AOD $550 \mathrm{~nm}$ value within $10 \mathrm{~min}$ (before or after) of the satellite overpass time was selected, and the mean $550 \mathrm{~nm}$ LaSRC AOD over a $1470 \mathrm{~m} \times 1470 \mathrm{~m}$ image window centered on the AERONET site location was derived. If more than half of the satellite AOD retrievals in the $1470 \mathrm{~m} \times 1470 \mathrm{~m}$ window were cloudy or missing, the data were discarded. A 10-min period was used because the median closest temporal difference between the satellite overpass times and the AERONET measurements for the 2016 data was 2.9 min (Sentinel-2A) and $4.1 \mathrm{~min}$ (Landsat-8), and the median second closest temporal difference was $7.7 \mathrm{~min}$ (Sentinel-2A) and $9.5 \mathrm{~min}$ (Landsat-8). In China, the annual urban mean wind speed is $2.4 \mathrm{~m} / \mathrm{s} \mathrm{[49]}$ and so in 10 min aerosols could be blown $1440 \mathrm{~m}$, which is smaller than the $1470 \mathrm{~m}$ window dimension. Using too large a window size will increase the likelihood of averaging aerosols from different sources, which is a concern in urban environments where aerosols may vary spatially quite rapidly.

\section{Results}

\subsection{Contemporaneous Data Availability and Example Annual Satellite and AERONET AOD Data Comparison}

Table 2 summarizes the number of contemporaneous satellite and AERONET AOD data sets in 2016. Due to the stringent selection criteria (Section 3.2), six of the 26 AERONET sites had no remaining contemporaneous data, leaving a total of 20 urban AERONET sites considered in the reminder of this study. There were generally more contemporaneous Sentinel-2A than Landsat-8 data due to the greater Sentinel-2A temporal data availability. There were more Level 1.5 data than Level 2.0 AERONET data due to the additional quality assurance used to generate the Level 2.0 data [29]. On average, among the 20 sites in 2016, there were 5.9 Level 1.5 and 4.45 Level 2.0 AERONET AOD and Sentinel-2A contemporaneous data pairs, and on average for Landsat-8, there were 5.3 Level 1.5 and 3.35 Level 2.0 AERONET AOD data pairs.

The Beijing-CAMS and XiangHe AERONET sites had the greatest number of contemporaneous satellite and AERONET data pairs. Figure 2 illustrates the AERONET Level 2.0 AOD (black dots) and the contemporaneous Landsat-8 (blue circles) and Sentinel-2A (red circles) AOD for the Beijing-CAMS site. The vertical lines in Figure 2 are drawn to connect the satellite and AERONET AOD retrievals (by definition they occurred within $10 \mathrm{~min}$ ) and illustrate that the Sentinel-2A and Landsat- 8 sensors usually overpass on different days. On day 221 (8 August) both Landsat- 8 and Sentinel-2A overpassed the AERONET site on the same day, and the difference between the satellite and contemporaneous AERONET AOD data was less than 0.2. Specifically, the Landsat-8 AOD was 0.295 (sensed at 02:53:32.9 UTC) compared to the temporally closest AERONET AOD of 0.193 (02:51:11 UTC), and the Sentinel-2A AOD was 0.337 (02:59:14.1 UTC) compared to the temporally closest AERONET AOD of 0.143 (03:00:57 UTC).

The biggest Beijing-CAMS site satellite AERONET AOD difference occurred on day 181 (29 June) when the AERONET AOD was 1.117 (03:06:58 UTC) and the Sentinel-2A AOD was 1.948 (03:06:27.6 UTC). However, visual inspection of the day 181 Sentinel-2A $1470 \mathrm{~m} \times 1470 \mathrm{~m}$ window revealed that this was due to residual cloud contamination (nearly one third of the Sentinel-2A pixels were cloud contaminated but only about half were labeled by the LaSRC algorithm as cloudy). Cloud contamination is a significant error source for satellite AOD retrieval and usually results in inflated 
AOD retrieval [50,51]. Examination of the other days with contemporaneous data in 2016 indicated no other cloud detection omission errors. In summary, for the illustrated year of Beijing-CAMS site data, after discarding the day 181 cloud contaminated data, the root mean square deviation (RMSD) between the AERONET AOD and the satellite AOD was 0.183 for Landsat- $8(n=12)$ and 0.102 for Sentinel-2A $(n=28)$. The correlation between the satellite AOD and the AERONET AOD for the year was 0.967 for Landsat- 8 and 0.962 for Sentinel-2A.

Table 2. Summary of the 26 urban AERONET sites (Figure 1), the number of days with 2016 AERONET data, and the number of contemporaneous LaSRC satellite AOD and AERONET AOD data pairs.

\begin{tabular}{|c|c|c|c|}
\hline $\begin{array}{c}\text { AERONET Site } \\
\text { (Latitude, Longitude) }\end{array}$ & $\begin{array}{c}\text { Number of Days in } 2016 \\
\text { with AERONET Level } \\
1.5 \text { (Level 2.0) Data }\end{array}$ & $\begin{array}{c}\text { Number of Contemporaneous } \\
\text { Landsat-8 and AERONET } \\
\text { Level 1.5 (Level 2.0) AOD Data Pairs }\end{array}$ & $\begin{array}{l}\text { Number of Contemporaneous } \\
\text { Sentinel-2A and AERONET } \\
\text { Level 1.5 (Level 2.0) AOD Data Pairs }\end{array}$ \\
\hline $\begin{array}{c}\text { AOE_Baotou } \\
\left(40.852^{\circ} \mathrm{N}, 109.629^{\circ} \mathrm{E}\right)\end{array}$ & $173(0)$ & $13(0)$ & $9(0)$ \\
\hline $\begin{array}{c}\text { Beijing } \\
\left(39.977^{\circ} \mathrm{N}, 116.381^{\circ} \mathrm{E}\right)\end{array}$ & $243(243)$ & $11(11)$ & $22(22)$ \\
\hline $\begin{array}{c}\text { Beijing-CAMS } \\
\left(39.933^{\circ} \mathrm{N}, 116.317^{\circ} \mathrm{E}\right)\end{array}$ & 299 (299) & $12(12)$ & $29(29)$ \\
\hline $\begin{array}{c}\text { Beijing_PKU } \\
\left(39.992^{\circ} \mathrm{N}, 116.310^{\circ} \mathrm{E}\right)\end{array}$ & $147(0)$ & $3(0)$ & $11(0)$ \\
\hline $\begin{array}{c}\text { Beijing_RADI } \\
\left(40.005^{\circ} \mathrm{N}, 116.379^{\circ} \mathrm{E}\right)\end{array}$ & $224(0)$ & $4(0)$ & $3(0)$ \\
\hline $\begin{array}{l}\text { Hong_Kong_PolyU } \\
\left(22.303^{\circ} \mathrm{N}, 114.180^{\circ} \mathrm{E}\right)\end{array}$ & $53(53)$ & $0(0)$ & $1(1)$ \\
\hline $\begin{array}{l}\text { Hong_Kong_Sheung } \\
\left(22.483^{\circ} \mathrm{N}, 114.117^{\circ} \mathrm{E}\right)\end{array}$ & $52(52)$ & $3(3)$ & $0(0)$ \\
\hline $\begin{array}{c}\text { QOMS_CAS } \\
\left(28.365^{\circ} \mathrm{N}, 86.948^{\circ} \mathrm{E}\right)\end{array}$ & 198 (198) & $2(2)$ & $0(0)$ \\
\hline $\begin{array}{c}\text { SONET_Harbin } \\
\left(45.705^{\circ} \mathrm{N}, 126.614^{\circ} \mathrm{E}\right)\end{array}$ & $33(0)$ & $2(0)$ & $0(0)$ \\
\hline $\begin{array}{c}\text { SONET_Hefei } \\
\left(31.905^{\circ} \mathrm{N}, 117.162^{\circ} \mathrm{E}\right)\end{array}$ & $23(0)$ & $0(0)$ & $0(0)$ \\
\hline $\begin{array}{c}\text { SONET_Nanjing } \\
\left(32.115^{\circ} \mathrm{N}, 118.957^{\circ} \mathrm{E}\right)\end{array}$ & $11(0)$ & $0(0)$ & $0(0)$ \\
\hline $\begin{array}{l}\text { SONET_Shanghai } \\
\left(31.284^{\circ} \mathrm{N}, 121.481^{\circ} \mathrm{E}\right)\end{array}$ & $16(0)$ & $0(0)$ & $1(0)$ \\
\hline $\begin{array}{c}\text { SONET_Xingtai } \\
\left(37.182^{\circ} \mathrm{N}, 114.360^{\circ} \mathrm{E}\right)\end{array}$ & $22(0)$ & $0(0)$ & $0(0)$ \\
\hline $\begin{array}{l}\text { SONET_Zhoushan } \\
\left(29.994^{\circ} \mathrm{N}, 122.188^{\circ} \mathrm{E}\right)\end{array}$ & $13(0)$ & $2(0)$ & $0(0)$ \\
\hline $\begin{array}{c}\text { Taihu } \\
\left(31.421^{\circ} \mathrm{N}, 120.215^{\circ} \mathrm{E}\right)\end{array}$ & 153 (129) & $2(2)$ & $5(5)$ \\
\hline $\begin{array}{c}\text { XiangHe } \\
\left(39.754^{\circ} \mathrm{N}, 116.962^{\circ} \mathrm{E}\right)\end{array}$ & $289(289)$ & $18(18)$ & $23(23)$ \\
\hline $\begin{array}{c}\text { XuZhou-CUMT } \\
\left(34.217^{\circ} \mathrm{N}, 117.142^{\circ} \mathrm{E}\right)\end{array}$ & $258(0)$ & $15(0)$ & $4(0)$ \\
\hline $\begin{array}{c}\text { Alishan } \\
\left(23.508^{\circ} \mathrm{N}, 120.813^{\circ} \mathrm{E}\right)\end{array}$ & $14(14)$ & $0(0)$ & $0(0)$ \\
\hline $\begin{array}{c}\text { Bamboo } \\
\left(25.187^{\circ} \mathrm{N}, 121.535^{\circ} \mathrm{E}\right)\end{array}$ & $11(11)$ & $0(0)$ & $0(0)$ \\
\hline $\begin{array}{l}\text { Cape_Fuguei_Station } \\
\left(25.297^{\circ} \mathrm{N}, 121.538^{\circ} \mathrm{E}\right)\end{array}$ & $16(0)$ & $0(0)$ & $0(0)$ \\
\hline $\begin{array}{c}\text { Chen-Kung_Univ } \\
\left(23.000^{\circ} \mathrm{N}, 120.217^{\circ} \mathrm{E}\right)\end{array}$ & $137(80)$ & $2(2)$ & $1(0)$ \\
\hline $\begin{array}{c}\text { Chiayi } \\
\left(23.496^{\circ} \mathrm{N}, 120.496^{\circ} \mathrm{E}\right)\end{array}$ & $144(144)$ & $5(5)$ & $2(2)$ \\
\hline $\begin{array}{c}\text { Douliu } \\
\left(23.712^{\circ} \mathrm{N}, 120.545^{\circ} \mathrm{E}\right)\end{array}$ & 19 (19) & $0(0)$ & $1(1)$ \\
\hline $\begin{array}{c}\text { EPA-NCU } \\
\left(24.968^{\circ} \mathrm{N}, 121.185^{\circ} \mathrm{E}\right)\end{array}$ & 201 (201) & $3(3)$ & $2(2)$ \\
\hline $\begin{array}{c}\text { Lulin } \\
\left(23.469^{\circ} \mathrm{N}, 120.874^{\circ} \mathrm{E}\right)\end{array}$ & 190 (190) & $4(4)$ & $0(0)$ \\
\hline $\begin{array}{c}\text { Taipei_CWB } \\
\left(25.030^{\circ} \mathrm{N}, 121.500^{\circ} \mathrm{E}\right)\end{array}$ & 188 (188) & $5(5)$ & $4(4)$ \\
\hline
\end{tabular}




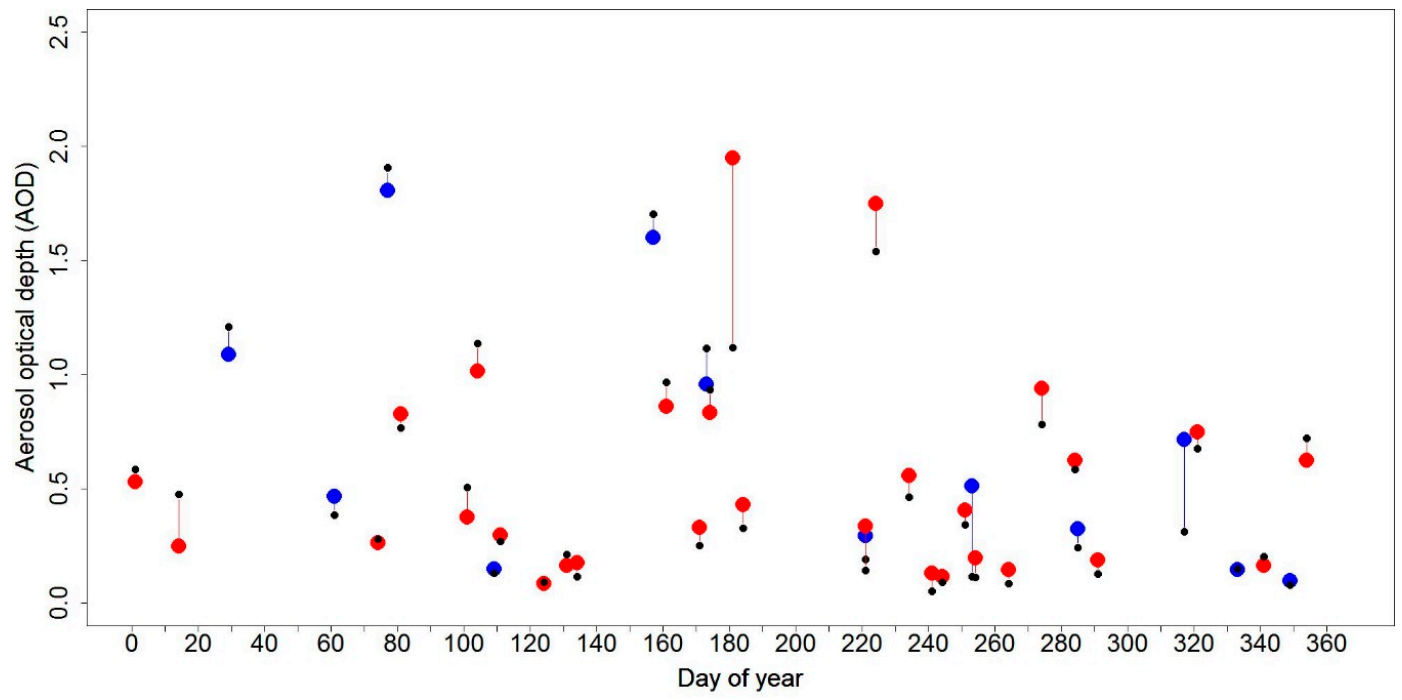

Figure 2. Beijing-CAMS site 2016 results showing the AERONET Level 2.0 AOD (41 small black dots), the Sentinel-2A ( 29 red filled circles) and the Landsat-8 (12 blue filled circles) AOD values. The vertical lines connect the satellite AOD retrievals with the contemporaneous AERONET AOD measurements (always within $10 \mathrm{~min}$ of each other). Satellite AOD values are mean non-cloudy values derived from a $1470 \mathrm{~m} \times 1470 \mathrm{~m}$ window over the AERONET site. All AOD values are at $550 \mathrm{~nm}$.

\subsection{Satellite and AERONET AOD Comparison}

Figure 3 shows scatterplots of the contemporaneous Landsat- 8 and AERONET Level 1.5 (left) and Level 2.0 (right) AOD data over the urban sites for 2016. Three of the Landsat-8 overpasses had cloud detection omission errors and resulted in inflated Landsat-8 AOD values (filled circles); they occurred on 8 April (day 99) at the Taipei-CWB site, 12 June (day 164) at the QOMS_CAS site, and 4 December (day 339) at the Taipei-CWB site. The open circles show the remaining AOD pairs ( $\mathrm{n}=103$ for Level 1.5 and $n=64$ for Level 2.0) that were used for the statistics analysis. The results are similar considering the Level 1.5 and Level 2.0 AERONET data. The ordinary least squares (OLS) linear regression lines (black) show a high-level agreement $\left(\mathrm{r}^{2}>0.9\right.$; regression slopes close to unity and $>0.96$ ). The root mean square deviation (RMSD) between the Landsat-8 AOD and the AERONET AOD was 0.161 (Level 1.5) and 0.171 (Level 2). The Level 2 AOD provided higher RMSD likely because the errors in the satellite AOD retrievals are larger than the errors in the AERONET AOD measurements; any improvement of the quality assured Level 2.0 over the Level 1.5 AERONET AOD is marginal compared to the satellite AOD retrieval errors.

Figure 4 shows scatterplots of the contemporaneous Sentinel-2A and AERONET AOD data over the urban sites for 2016. The open circles show the valid AOD pairs ( $n=116$ for Level 1.5 and $n=87$ for Level 2.0) used for the statistical analysis. Two outliers (filled circles) were due to cloud detection omission errors in Sentinel-2A images acquired on June 29 (day 181) at the Beijing-CAMS site (also evident in Figure 2), and on August 9 (day 222) at the Taipei_CWB site. They are not considered in the statistical analysis. The Sentinel-2A AOD retrievals show high agreement (OLS regression slopes close to unity and $>0.96 ; \mathrm{r}^{2}>0.920$; RMSD $<0.110$ ) with both the AERONET Level 1.5 and Level 2.0 AOD data. Similar to the Landsat-8 results (Figure 3), there are no significant differences between the Level 1.5 (left) and Level 2.0 (right) results.

Notably, more than $13 \%$ of the AERONET Level 2.0 AOD values were $>1.0$ (indicating very hazy urban conditions). For five overpass dates the AERONET AOD values were $>1.5$; all occurred in Beijing (at AERONET sites: Beijing, Beijing-CAMS, and XiangHe) in the months of March, June, July, August, and September. These high AOD values were not due to undetected clouds, as the AERONET Ångström exponent values for the five overpass dates varied from 0.8680 to 1.3127 (mean 1.0941) and clouds typically have Ångström exponent values $<0.5$ [52]. The greatest AERONET AOD value with 
contemporaneous non-cloudy Landsat- 8 satellite data was 1.940 and occurred at the Beijing AERONET site on July 7th (day 189), and the greatest AERONET AOD value with contemporaneous non-cloudy Satellite-2A satellite data was 2.094 and occurred at the Beijing_PKU site on August 11th (day 224). On these two days the difference between the satellite and AERONET AOD values was $<0.12$. These results, and those illustrated in Figures 3 and 4, indicate the ability of the LaSRC satellite AOD retrieval algorithm to work over a wide range of urban AOD values.
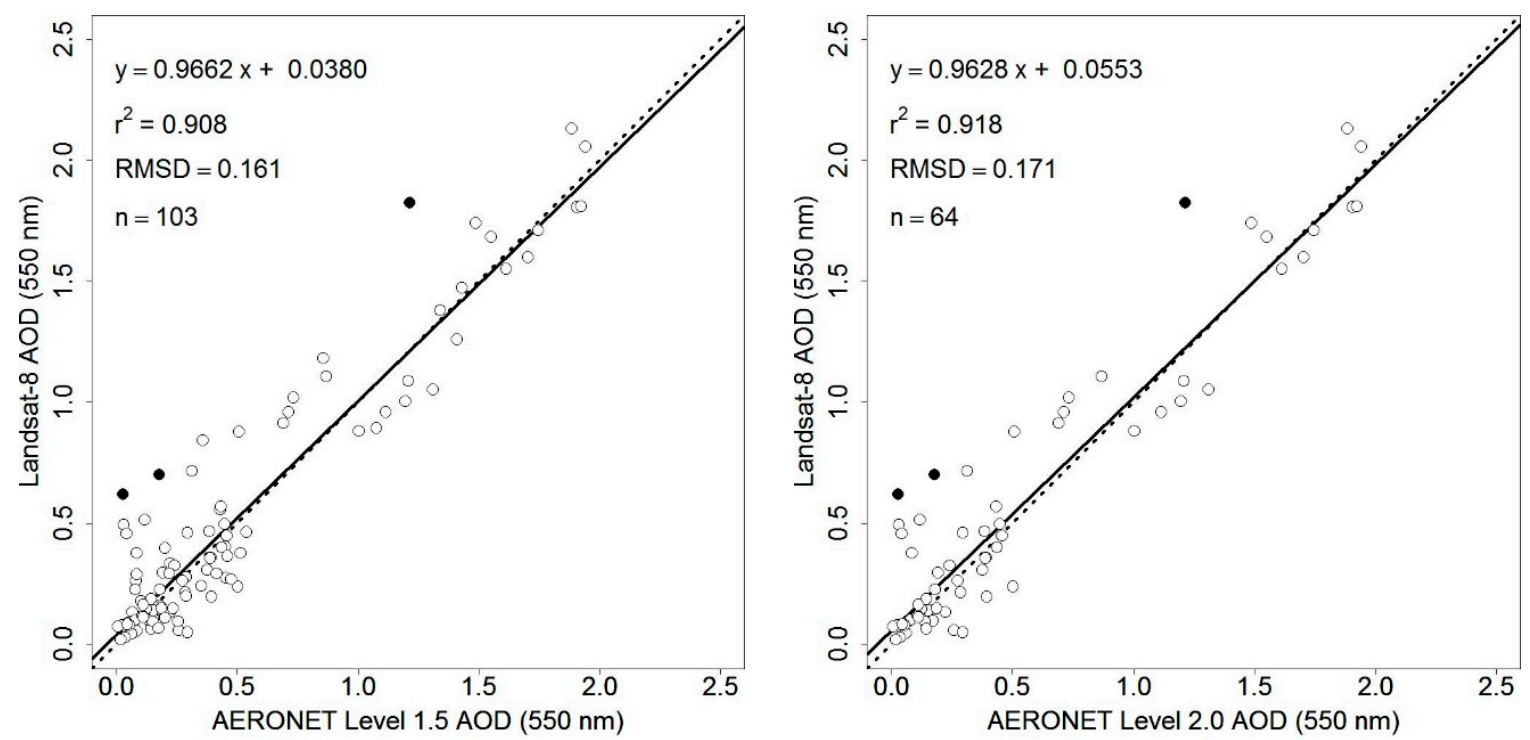

Figure 3. Scatterplots of the Landsat-8 AOD against the contemporaneous AERONET Level 1.5 (left) and Level 2.0 (right) AOD data over the urban AERONET sites for 2016. The three filled circles are outliers due to Landsat- 8 cloud detection omission errors and are not used in statistics analysis. The solid lines show ordinary least square regression lines. The dotted lines are 1:1 lines superimposed for reference.
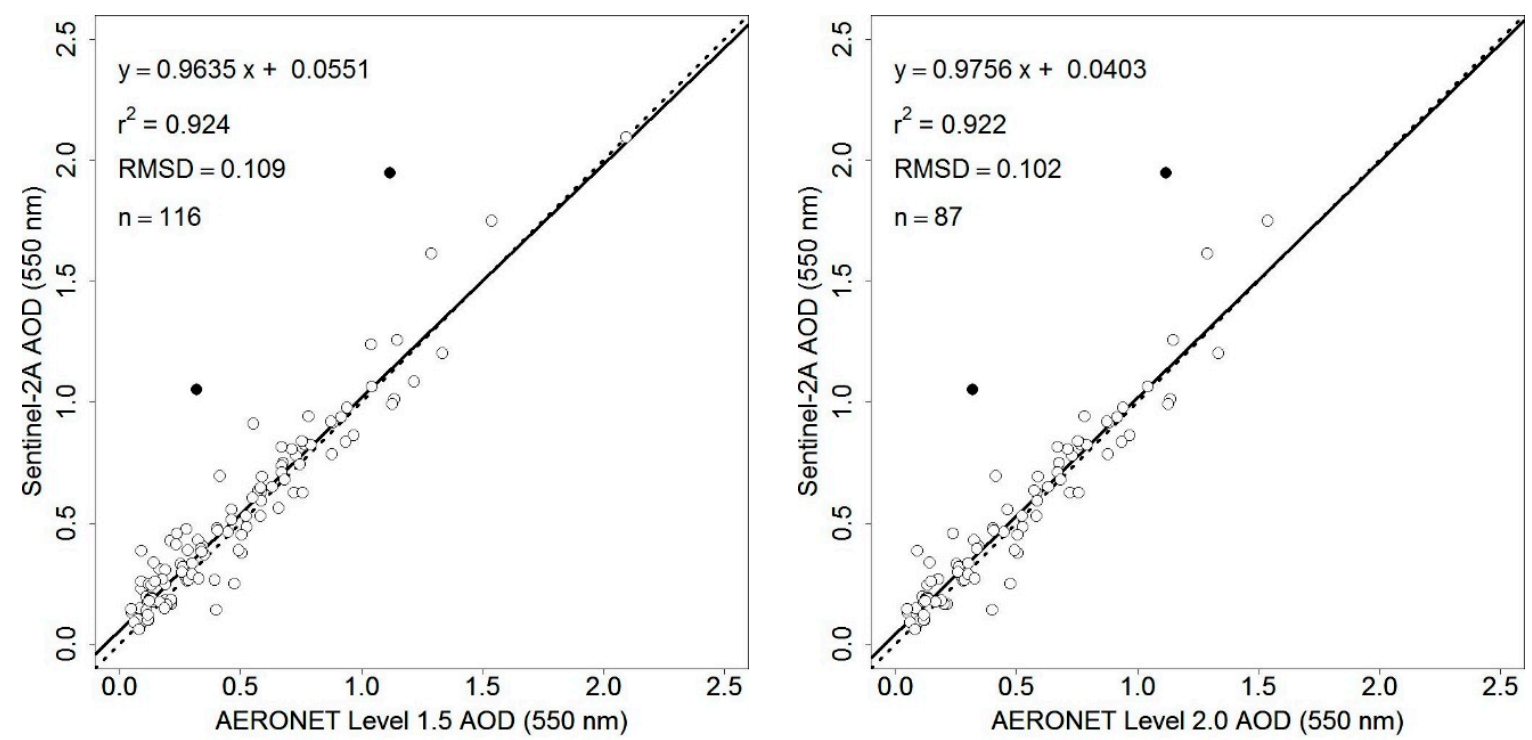

Figure 4. Scatterplots of the Sentinel-2A AOD against the contemporaneous AERONET Level 1.5 (left) and Level 2.0 (right) AOD data over the urban AERONET sites for 2016. The two filled circles are outliers due to Sentinel-2A cloud detection omission errors and are not used in statistics analysis. The solid lines show ordinary least square regression lines. The dotted lines are 1:1 lines superimposed for reference. 


\section{Discussion}

The criteria used to select contemporaneous medium resolution satellite and AERONET data across China were purposefully stringent to capture fine scale urban aerosol variations. The closest AERONET AOD value within 10 min of each satellite overpass was selected, and the mean LaSRC AOD over a $1470 \mathrm{~m} \times 1470 \mathrm{~m}$ image window centered on the AERONET site location was derived. $\mathrm{A} \pm 10$ min period was used to reflect the approximately three minutes frequency of most AERONET data [29] and because the median closest and second closest temporal differences between the satellite overpass times and the AERONET measurements for the 2016 data were less than $10 \mathrm{~min}$. A $1470 \mathrm{~m} \times$ $1470 \mathrm{~m}$ image window size was used, as it corresponds to an integer multiple of the Landsat-8 $30 \mathrm{~m}$ and the Sentinel-2A $10 \mathrm{~m}$ bands, and because in $10 \mathrm{~min}$ aerosols would not be transported completely across the window at the reported annual urban $2.4 \mathrm{~m} / \mathrm{s}$ mean wind speed [49]. We undertook a sensitivity analyses, considering $2970 \mathrm{~m} \times 2970 \mathrm{~m}$ and $5970 \mathrm{~m} \times 5970 \mathrm{~m}$ window dimensions for the same $\pm 10 \mathrm{~min}$ period, and found only small differences in the reported results (differences only in the second decimal place of the reported RMSD values).

Using large window sizes and long temporal periods as selection criteria will increase the likelihood of aerosols from different sources being compared between the AERONET and satellite AOD data. This is a concern in urban environments where aerosols may vary spatially quite rapidly. For example, Chen et al. [53] considered a year of PM2.5, PM10, and greenhouse gas concentration data from 35 Beijing municipal environmental monitoring stations and found significant spatial differences between urban, suburban, and traffic sites, and significant diurnal variations at individual sites. Similarly, Wang et al. [54] documented urban PM2.5 concentrations in the morning and evening that were nearly twice those in the mid-afternoon in northeast China. Previously, researchers have compared coarser spatial resolution but near daily MODIS AOD retrievals with AERONET AOD using temporal selection criteria of $\pm 30 \mathrm{~min}$ and spatial window side dimensions varying from $9 \mathrm{~km}$ to $50 \mathrm{~km}$ [9,20,55-58] and $\pm 7.5 \mathrm{~min}$ with a $10 \mathrm{~km}$ spatial window dimension [59]. An explicit study of spatial scaling effects, comparing MODIS AOD data with PM2.5 measurements in the Boston metropolitan area [22], found reduced correlation with increasing window size. Further research to undertake scaling analyses, including wind speed information, using the Landsat- 8 and Sentinel-2 AOD data is recommended, subject to the availability of data from a dense ground-based atmospheric monitoring network.

In this study ordinary least squares (OLS) linear regression was used to fit the LaSRC satellite AOD against the AERONET AOD. This is the conventional approach adopted by the majority of researchers because the errors in the AERONET AOD data are considerably smaller than those typically present in satellite AOD retrievals. We also examined the use of reduced major axis regression (RMA) which allows error in both the independent and dependent variables [60,61]. However, the OLS and RMA results were similar with linear regression line slope differences $<0.05$.

Recently, the LaSRC AOD algorithm was assessed, with seven other AOD algorithms, considering a year of Landsat- 8 and seven months of Sentinel-2A overpasses at 19 globally distributed urban and non-urban AERONET sites using a $\pm 15 \mathrm{~min}$ and $9 \mathrm{~km}$ window dimension [26]. The authors [26] reported that the Sentinel-2A LaSRC AOD performed the best among the different AOD algorithms, and, as in this study, the Landsat-8 LaSRC AOD was less accurate than the Sentinel-2A LaSRC AOD. The reasons for this sensor difference are unknown but are likely related to the higher spatial resolution of the Sentinel-2A compared to Landsat- 8 and to sensor spectral band differences. The uncertainty of the LaSRC derived AOD is due to a number of sources, like other AOD retrieval algorithms $([8,41,62])$, including the sensor radiance calibration uncertainty, cloud detection omission errors, and assumptions concerning the aerosol type and spectral variation in surface reflectance.

The current state-of-the-practice for global coverage satellite AOD monitoring is based on near daily, but coarse spatial resolution, polar-orbiting data, such as from MODIS, that may be spatially too coarse for monitoring urban pollution [22,63,64]. The Landsat- 8 and Sentinel-2A satellites provide a higher spatial resolution $(10 \mathrm{~m}$ to $30 \mathrm{~m})$ global coverage AOD monitoring capability but with 
lower temporal resolution. For example, in this study there were an average of 20 Landsat-8 and 30 Sentinel-2A overpasses per year over the Chinese cities. Data from the recently launched (March 2017) Sentinel-2B were not available for the study period, but combined with Sentinel-2A and Landsat-8, will increase the temporal observation frequency to a global median average revisit interval of 2.9 days with different overpass times [65]. Given their high accuracy in AOD retrieval, future research to investigate the combined use of Landsat- 8 and the two Sentinel-2 satellites for AOD monitoring is recommended.

\section{Conclusions}

In 2016 there were 26 urban AERONET sites across China with available data, and after applying the spatial and temporal selection criteria 20 sites remained with an annual total of 106 (Level 1.5) and 67 (Level 2.0) Landsat-8 AERONET AOD contemporaneous data pairs, and 118 (Level 1.5) and 89 (Level 2.0) Sentinel-2A AOD data pairs. The resulting AERONET data encompassed a wide range of AOD from clear days (minimum $=0.008$ ) to very hazy conditions (maximum $=2.094$ ). The greatest AOD values (>1.5) occurred in Beijing, suggesting that the Chinese capital was one of the most polluted cities in China in 2016.

The Landsat-8 and Sentinel-2A AOD retrievals agreed well with the AERONET AOD measurements (OLS linear regression slopes $>0.96, \mathrm{r}^{2}>0.90$, and RMSD $<0.175$ ) with no significant pattern of over- or under-estimation of the AOD. Although the AERONET Level 2.0 AOD data are quality assured, there were no pronounced differences between the results considering the Level 1.5 and considering the Level 2.0 AOD data. The Sentinel-2A AOD retrievals had slightly better agreement (RMSD < 0.11) with the contemporaneous AERONET AOD measurements than the Landsat-8 retrievals $($ RMSD $<0.175)$.

Author Contributions: Conceptualization, D.P.R. and H.K.Z.; Software, Z.L. and E.F.V.; Data curation, Z.L.; Writing—original draft preparation, Z.L., H.K.Z., and H.H.; Writing—review and editing, D.P.R., E.F.V., H.K.Z., Z.L., and H.H.

Funding: This research was funded by the NASA Land Cover/Land Use Change Multi-Source Land Imaging Science Program Grant NNX15AK94G and by NASA Making Earth System Data Records for Use in Research Environments (MEaSUREs) program (cooperative agreement NNX13AJ24A).

Acknowledgments: The European Space Agency and Copernicus program management and staff, and the USGS Landsat program management and staff, are thanked for the free provision of the Sentinel-2A and Landsat- 8 data respectively. The NASA Goddard AERONET site (https:/ / aeronet.gsfc.nasa.gov) is thanked for providing the free ground-based aerosol optical depth data.

Conflicts of Interest: The authors declare no conflict of interest.

\section{References}

1. Guo, S.; Hu, M.; Zamora, M.L.; Peng, J.; Shang, D.; Zheng, J.; Du, Z.; Wu, Z.; Shao, M.; Zeng, L.; et al. Elucidating severe urban haze formation in China. Proc. Natl. Acad. Sci. USA 2014, 111, 17373-17378. [CrossRef] [PubMed]

2. Guan, D.; Su, X.; Zhang, Q.; Peters, G.P.; Liu, Z.; Lei, Y.; He, K. The socioeconomic drivers of China's primary $\mathrm{PM}_{2.5}$ emissions. Environ. Res. Lett. 2014, 9, 024010. [CrossRef]

3. Rohde, R.A.; Muller, R.A. Air pollution in China: Mapping of concentrations and sources. PLoS ONE 2015, 10, e0135749. [CrossRef] [PubMed]

4. Peng, J.; Chen, S.; Lü, H.; Liu, Y.; Wu, J. Spatiotemporal patterns of remotely sensed $\mathrm{PM}_{2.5}$ concentration in China from 1999 to 2011. Remote Sens. Environ. 2016, 174, 109-121. [CrossRef]

5. Gao, J.; Woodward, A.; Vardoulakis, S.; Kovats, S.; Wilkinson, P.; Li, L.; Xu, L.; Li, J.; Yang, J.; Cao, L.; et al. Haze, public health and mitigation measures in China: A review of the current evidence for further policy response. Sci. Total Environ. 2017, 578, 148-157. [CrossRef] [PubMed]

6. Lu, Y.; Wang, Y.; Zuo, J.; Jiang, H.; Huang, D.; Rameezdeen, R. Characteristics of public concern on haze in China and its relationship with air quality in urban areas. Sci. Total Environ. 2018, 637, 1597-1606. [CrossRef] [PubMed] 
7. Kaufman, Y.J.; Tanré, D.; Boucher, O. A satellite view of aerosols in the climate system. Nature 2002, 419, 215-223. [CrossRef]

8. Kokhanovsky, A.A.; Deuzé, J.L.; Diner, D.J.; Dubovik, O.; Ducos, F.; Emde, C.; Garay, M.J.; Grainger, R.G.; Heckel, A.; Herman, M.; et al. The inter-comparison of major satellite aerosol retrieval algorithms using simulated intensity and polarization characteristics of reflected light. Atmos. Meas. Tech. 2010, 3, 909-932. [CrossRef]

9. Levy, R.C.; Mattoo, S.; Munchak, L.A.; Remer, L.A.; Sayer, A.M.; Patadia, F.; Hsu, N.C. The Collection 6 MODIS aerosol products over land and ocean. Atmos. Meas. Tech. 2013, 6, 2989. [CrossRef]

10. Wang, J.; Christopher, S.A. Intercomparison between satellite-derived aerosol optical thickness and PM2.5 mass: Implications for air quality studies. Geophys. Res. Lett. 2003, 30. [CrossRef]

11. Van Donkelaar, A.; Martin, R.V.; Brauer, M.; Kahn, R.; Levy, R.; Verduzco, C.; Villeneuve, P.J. Global estimates of ambient fine particulate matter concentrations from satellite-based aerosol optical depth: Development and application. Environ. Health Perspect. 2010, 118, 847. [CrossRef] [PubMed]

12. Kloog, I.; Chudnovsky, A.A.; Just, A.C.; Nordio, F.; Koutrakis, P.; Coull, B.A.; Lyapustin, A.; Wang, Y.; Schwartz, J. A new hybrid spatio-temporal model for estimating daily multi-year $\mathrm{PM}_{2.5}$ concentrations across northeastern USA using high resolution aerosol optical depth data. Atmos. Environ. 2014, 95, 581-590. [CrossRef] [PubMed]

13. Ma, Z.; Hu, X.; Sayer, A.M.; Levy, R.; Zhang, Q.; Xue, Y.; Tong, S.; Bi, J.; Huang, L.; Liu, Y. Satellite-based spatiotemporal trends in $\mathrm{PM}_{2.5}$ concentrations: China, 2004-2013. Environ. Health Perspect. 2015, 124, 184-192. [CrossRef] [PubMed]

14. Torres, O.; Bhartia, P.K.; Herman, J.R.; Sinyuk, A.; Ginoux, P.; Holben, B. A long-term record of aerosol optical depth from TOMS observations and comparison to AERONET measurements. J. Atmos. Sci. 2002, 59, 398-413. [CrossRef]

15. Leroy, M.; Deuzé, J.L.; Bréon, F.M.; Hautecoeur, O.; Herman, M.; Buriez, J.C.; Tanré, D.; Bouffies, S.; Chazette, P.; Roujean, J.L. Retrieval of atmospheric properties and surface bidirectional reflectances over land from POLDER/ADEOS. J. Geophys. Res. Atmos. 1997, 102, 17023-17037. [CrossRef]

16. Diner, D.J.; Abdou, W.; Ackerman, T.; Crean, K.; Gordon, H.; Kahn, R.; Martonchik, J.; McMuldroch, S.; Paradise, S.; Pinty, B.; et al. MISR Level 2 Aerosol Retrieval Algorithm Theoretical Basis; NASA: Greenbelt, MD, USA, 1999; JPL D11400.

17. Mei, L.; Rozanov, V.; Vountas, M.; Burrows, J.P.; Levy, R.C.; Lotz, W. Retrieval of aerosol optical properties using MERIS observations: Algorithm and some first results. Remote Sens. Environ. 2017, 197, 125-140. [CrossRef] [PubMed]

18. Jackson, J.M.; Liu, H.; Laszlo, I.; Kondragunta, S.; Remer, L.A.; Huang, J.; Huang, H.C. Suomi-NPP VIIRS aerosol algorithms and data products. J. Geophys. Res. Atmos. 2013, 118. [CrossRef]

19. Kikuchi, M.; Murakami, H.; Suzuki, K.; Nagao, T.M.; Higurashi, A. improved hourly estimates of aerosol optical thickness using spatiotemporal variability derived from Himawari-8 geostationary satellite. IEEE Trans. Geosci. Remote Sens. 2018, 56, 3442-3455. [CrossRef]

20. Gupta, P.; Remer, L.A.; Levy, R.C.; Mattoo, S. Validation of MODIS $3 \mathrm{~km}$ land aerosol optical depth from NASA's EOS Terra and Aqua missions. Atmos. Meas. Tech. 2018, 11, 3145. [CrossRef]

21. Lyapustin, A.; Wang, Y.; Korkin, S.; Huang, D. MODIS Collection 6 MAIAC algorithm. Atmos. Meas. Tech. 2018, 11, 5741-5765. [CrossRef]

22. Chudnovsky, A.A.; Kostinski, A.; Lyapustin, A.; Koutrakis, P. Spatial scales of pollution from variable resolution satellite imaging. Environ. Pollut. 2013, 172, 131-138. [CrossRef]

23. Zhang, Y.L.; Cao, F. Fine particulate matter $\left(\mathrm{PM}_{2.5}\right)$ in China at a city level. Sci. Rep. 2015, 5, 14884. [CrossRef] [PubMed]

24. He, J.; Wu, L.; Mao, H.; Liu, H.; Jing, B.; Yu, Y.; Ren, P.; Feng, C.; Liu, X. Development of a vehicle emission inventory with high temporal-spatial resolution based on NRT traffic data and its impact on air pollution in Beijing-Part 2: Impact of vehicle emission on urban air quality. Atmos. Chem. Phys. 2016, 16, 3171-3184. [CrossRef]

25. Sun, L.; Wei, J.; Bilal, M.; Tian, X.; Jia, C.; Guo, Y.; Mi, X. Aerosol optical depth retrieval over bright areas using Landsat 8 OLI images. Remote Sens. 2016, 8, 23. [CrossRef] 
26. Doxani, G.; Vermote, E.; Roger, J.C.; Gascon, F.; Adriaensen, S.; Frantz, D.; Hagolle, O.; Hollstein, A.; Kirches, G.; Li, F.; et al. Atmospheric correction inter-comparison exercise. Remote Sens. 2018, 10, 352. [CrossRef]

27. Holben, B.N.; Eck, T.F.; Slutsker, I.; Tanre, D.; Buis, J.P.; Setzer, A.; Vermote, E.; Reagan, J.A.; Kaufman, Y.J.; Nakajima, T.; et al. AERONET-A federated instrument network and data archive for aerosol characterization. Remote Sens. Environ. 1998, 66, 1-16. [CrossRef]

28. Dubovik, O.; Holben, B.; Eck, T.F.; Smirnov, A.; Kaufman, Y.J.; King, M.D.; Tanré, D.; Slutsker, I. Variability of absorption and optical properties of key aerosol types observed in worldwide locations. J. Atmos. Sci. 2002, 59, 590-608. [CrossRef]

29. Giles, D.M.; Sinyuk, A.; Sorokin, M.; Schafer, J.S.; Smirnov, A.; Slutsker, I.; Eck, T.F.; Holben, B.N.; Lewis, J.; Campbell, J.; et al. Advancements in the Aerosol Robotic Network AERONET) Version 3 Database-Automatic Quality Assurance of Sun Photometer Aerosol Optical Depth. Atmos. Meas. Tech. 2018, in preparation. [CrossRef]

30. Roy, D.P.; Wulder, M.A.; Loveland, T.R.; Woodcock, C.E.; Allen, R.G.; Anderson, M.C.; Helder, D.; Irons, J.R.; Johnson, D.M.; Kennedy, R.; et al. Landsat-8: Science and product vision for terrestrial global change research. Remote Sens. Environ. 2014, 145, 154-172. [CrossRef]

31. Loveland, T.R.; Irons, J.R. Landsat 8: The plans, the reality, and the legacy. Remote Sens. Environ. 2016, 185, 1-6. [CrossRef]

32. Dwyer, J.L.; Roy, D.P.; Sauer, B.; Jenkerson, C.B.; Zhang, H.K.; Lymburner, L. Analysis Ready Data: Enabling analysis of the Landsat archive. Remote Sens. 2018, 10, 1363.

33. Storey, J.; Choate, M.; Lee, K. Landsat 8 Operational Land Imager on-orbit geometric calibration and performance. Remote Sens. 2014, 6, 11127-11152. [CrossRef]

34. Drusch, M.; Del Bello, U.; Carlier, S.; Colin, O.; Fernandez, V.; Gascon, F.; Hoersch, B.; Isola, C.; Laberinti, P.; Martimort, P.; et al. Sentinel-2: ESA's optical high-resolution mission for GMES operational services. Remote Sens. Environ. 2012, 120, 25-36. [CrossRef]

35. Roy, D.P.; Li, J.; Zhang, H.K.; Yan, L. Best practices for the reprojection and resampling of Sentinel-2 Multi Spectral Instrument Level 1C data. Remote Sens. Lett. 2016, 7, 1023-1032. [CrossRef]

36. Yan, L.; Roy, D.P.; Li, Z.; Zhang, H.K.; Huang, H. Sentinel-2A multi-temporal misregistration characterization and an orbit-based sub-pixel registration methodology. Remote Sens. Environ. 2018, 215, 495-506. [CrossRef]

37. Gascon, F.; Bouzinac, C.; Thépaut, O.; Jung, M.; Francesconi, B.; Louis, J.; Lonjou, V.; Lafrance, B.; Massera, S.; Gaudel-Vacaresse, A.; et al. Copernicus Sentinel-2A calibration and products validation status. Remote Sens. 2017, 9, 584. [CrossRef]

38. Vermote, E.F.; El Saleous, N.Z.; Justice, C.O. Atmospheric correction of MODIS data in the visible to middle infrared: First results. Remote Sens. Environ. 2002, 83, 97-111. [CrossRef]

39. Roy, D.P.; Qin, Y.; Kovalskyy, V.; Vermote, E.F.; Ju, J.; Egorov, A.; Hansen, M.C.; Kommareddy, I.; Yan, L. Conterminous United States demonstration and characterization of MODIS-based Landsat ETM+ atmospheric correction. Remote Sens. Environ. 2014, 140, 433-449. [CrossRef]

40. Kaufman, Y.J.; Tanré, D.; Remer, L.A.; Vermote, E.F.; Chu, A.; Holben, B.N. Operational remote sensing of tropospheric aerosol over land from EOS moderate resolution imaging spectroradiometer. J. Geophys. Res. Atmos. 1997, 102, 17051-17067. [CrossRef]

41. Vermote, E.; Justice, C.; Claverie, M.; Franch, B. Preliminary analysis of the performance of the Landsat 8/OLI land surface reflectance product. Remote Sens. Environ. 2016, 185, 46-56. [CrossRef]

42. Claverie, M.; Ju, J.; Masek, J.G.; Dungan, J.L.; Vermote, E.F.; Roger, J.C.; Skakun, S.V.; Justice, C. The Harmonized Landsat and Sentinel-2 surface reflectance data set. Remote Sens. Environ. 2018, 219, 145-161. [CrossRef]

43. Zhang, H.K.; Roy, D.P.; Yan, L.; Li, Z.; Huang, H.; Vermote, E.; Skakun, S.; Roger, J.C. Characterization of Sentinel-2A and Landsat- 8 top of atmosphere, surface, and nadir BRDF adjusted reflectance and NDVI differences. Remote Sens. Environ. 2018, 215, 482-494. [CrossRef]

44. Kotchenova, S.Y.; Vermote, E.F. Validation of a vector version of the $6 \mathrm{~S}$ radiative transfer code for atmospheric correction of satellite data. Part II. Homogeneous Lambertian and anisotropic surfaces. Appl. Opt. 2007, 46, 4455-4464. [CrossRef] [PubMed]

45. King, M.D.; Kaufman, Y.J.; Tanré, D.; Nakajima, T. Remote sensing of tropospheric aerosols from space: Past, present, and future. Bull. Am. Meteorol. Soc. 1999, 80, 2229-2260. [CrossRef] 
46. Schuster, G.L.; Dubovik, O.; Holben, B.N. Angstrom exponent and bimodal aerosol size distributions. J. Geophys. Res. Atmos. 2006, 111. [CrossRef]

47. Levy, R.C.; Remer, L.A.; Kleidman, R.G.; Mattoo, S.; Ichoku, C.; Kahn, R.; Eck, T.F. Global evaluation of the Collection 5 MODIS dark-target aerosol products over land. Atmos. Chem. Phys. 2010, 10, 10399-10420. [CrossRef]

48. Sayer, A.M.; Hsu, N.C.; Bettenhausen, C.; Jeong, M.J. Validation and uncertainty estimates for MODIS Collection 6 "Deep Blue" aerosol data. J. Geophys. Res. Atmos. 2013, 118, 7864-7872. [CrossRef]

49. Guo, H.; Xu, M.; Hu, Q. Changes in near-surface wind speed in China: 1969-2005. Int. J. Climatol. 2011, 31, 349-358. [CrossRef]

50. Kaufman, Y.J.; Remer, L.A.; Tanré, D.; Li, R.R.; Kleidman, R.; Mattoo, S.; Levy, R.C.; Eck, T.F.; Holben, B.N.; Ichoku, C.; et al. A critical examination of the residual cloud contamination and diurnal sampling effects on MODIS estimates of aerosol over ocean. IEEE Trans. Geosci. Remote Sens. 2005, 43, 2886-2897. [CrossRef]

51. Zhao, T.X.P.; Chan, P.K.; Heidinger, A.K. A global survey of the effect of cloud contamination on the aerosol optical thickness and its long-term trend derived from operational AVHRR satellite observations. J. Geophys. Res. Atmos. 2013, 118, 2849-2857. [CrossRef]

52. Smirnov, A.; Holben, B.N.; Eck, T.F.; Dubovik, O.; Slutsker, I. Cloud-screening and quality control algorithms for the AERONET database. Remote Sens. Environ. 2000, 73, 337-349. [CrossRef]

53. Chen, W.; Tang, H.; Zhao, H. Diurnal, weekly and monthly spatial variations of air pollutants and air quality of Beijing. Atmos. Environ. 2015, 119, 21-34. [CrossRef]

54. Wang, Y.Q.; Zhang, X.Y.; Sun, J.Y.; Zhang, X.C.; Che, H.Z.; Li, Y. Spatial and temporal variations of the concentrations of $\mathrm{PM}_{10}, \mathrm{PM}_{2.5}$ and $\mathrm{PM}_{1}$ in China. Atmos. Chem. Phys. 2015, 15, 13585-13598. [CrossRef]

55. Ichoku, C.; Chu, D.A.; Mattoo, S.; Kaufman, Y.J.; Remer, L.A.; Tanré, D.; Slutsker, I.; Holben, B.N. A spatiotemporal approach for global validation and analysis of MODIS aerosol products. Geophys. Res. Lett. 2002, 29, MOD1-1. [CrossRef]

56. Chu, D.A.; Kaufman, Y.J.; Ichoku, C.; Remer, L.A.; Tanré, D.; Holben, B.N. Validation of MODIS aerosol optical depth retrieval over land. Geophys. Res. Lett. 2002, 29, MOD2-1. [CrossRef]

57. Lyapustin, A.; Wang, Y.; Laszlo, I.; Kahn, R.; Korkin, S.; Remer, L.; Levy, R.; Reid, J.S. Multiangle implementation of atmospheric correction (MAIAC): 2. Aerosol algorithm. J. Geophys. Res. Atmos. 2011, 116. [CrossRef]

58. Nichol, J.E.; Bilal, M. Validation of MODIS $3 \mathrm{~km}$ resolution aerosol optical depth retrievals over Asia. Remote Sens. 2016, 8, 328. [CrossRef]

59. Xie, Y.; Zhang, Y.; Xiong, X.; Qu, J.J.; Che, H. Validation of MODIS aerosol optical depth product over China using CARSNET measurements. Atmos. Environ. 2011, 45, 5970-5978. [CrossRef]

60. Cohen, W.B.; Maiersperger, T.K.; Gower, S.T.; Turner, D.P. An improved strategy for regression of biophysical variables and Landsat ETM+ data. Remote Sens. Environ. 2003, 84, 561-571. [CrossRef]

61. Smith, R.J. Use and misuse of the reduced major axis for line-fitting. Am. J. Phys. Anthropol. 2009, 140, 476-486. [CrossRef]

62. Li, Z.; Zhao, X.; Kahn, R.; Mishchenko, M.; Remer, L.; Lee, K.H.; Wang, M.; Laszlo, I.; Nakajima, T.; Maring, H. Uncertainties in satellite remote sensing of aerosols and impact on monitoring its long-term trend: A review and perspective. Ann. Geophys. 2009, 27, 2755-2770. [CrossRef]

63. Li, C.; Lau, A.; Mao, J.; Chu, D. Retrieval, validation, and application of the 1-km aerosol optical depth from MODIS measurements over Hong Kong. IEEE Trans. Geosci. Remote Sens. 2005, 43, 2650-2658.

64. Hu, X.; Waller, L.A.; Lyapustin, A.; Wang, Y.; Al-Hamdan, M.Z.; Crosson, W.L.; Estes, M.G., Jr.; Estes, S.M.; Quattrochi, D.A.; Puttaswamy, S.J.; Liu, Y. Estimating ground-level $\mathrm{PM}_{2.5}$ concentrations in the Southeastern United States using MAIAC AOD retrievals and a two-stage model. Remote Sens. Environ. 2014, 140, $220-232$. [CrossRef]

65. Li, J.; Roy, D.P. A global analysis of Sentinel-2A, Sentinel-2B and Landsat-8 data revisit intervals and implications for terrestrial monitoring. Remote Sens. 2017, 9, 902.

(C) 2019 by the authors. Licensee MDPI, Basel, Switzerland. This article is an open access article distributed under the terms and conditions of the Creative Commons Attribution (CC BY) license (http://creativecommons.org/licenses/by/4.0/). 